TOMASZ GRALA* - POZNAŃ

\title{
ORGANIZACJA ADMINISTRACJI PAŃSTWA ZAKONNEGO W PRUSACH DO KOŃCA XIII WIEKU
}

Zakon Krzyżacki powstał jako ostatni, spośród trzech wielkich zakonów rycerskich, założonych podczas wypraw krzyżowych w Ziemi Świętej. Spośród innych zakonów wyróżniał się głównie dążeniem utworzenia własnego władztwa terytorialnego. Warto przy tym pamiętać, że Zakon Krzyżacki wprawdzie powiększał swoje terytoria, umacniał i rozszerzał swoją władzę, lecz zawsze pozostawał zakonem. Jego istnienie od początku było związane z polityką królów niemieckich i cesarzy rzymskich. Niepowodzeniem zakończyły się próby utworzenia własnego władztwa w Ziemi Świętej oraz na zdobytym przez nich terytorium Borsy. Swe zamiary Krzyżacy zrealizowali dopiero po usadowieniu się nad dolną Wisłą. W wyniku dokonanego podboju ziem pruskich, z pomocą krzyżowców z Niemiec i Europy Zachodniej terytorium państwa Zakonu Krzyżackiego w XIII w. tworzyły ziemia chełmińska i Prusy ${ }^{1}$. W pierwszym okresie podboju Krzyżaków wspierali również książęta polscy. Od początku swego istnienia państwo zakonne miało zarówno charakter feudalny jak i teokratyczny, co wywarło wpływ na przeprowadzone na tym obszarze podziały administracyjne ${ }^{2}$. Sprawnie działająca administracja była jednym z czynników warunkujących rozwój państwa krzyżackiego. Jej rysem charakterystycznym był podział na komturstwa, których liczba nie była stała, także zasięg niektórych ulegał zmianie. Jednak w ogólnym zarysie ten pierwotny podział przetrwał aż do upadku państwa zakonnego w Prusach. Grupie Krzyżaków pod przewodem ich Wielkiego Mistrza Hermana von Salzy udało się stworzyć, w trudnym okresie dla zakonów rycerskich powstałych

* Tomasz Grala - mgr historii, doktorant w Instytucie Historii Uniwersytetu Adama Mickiewicza w Poznaniu.

${ }^{1}$ R. Czaja, Aneks: Terytorium państwa zakonu krzyżackiego w Prusach w XIII-XV wieku,w: Państwo zakonu krzyżackiego w Prusach. Podziały administracyjne i kościelne w XIII-XVI wieku, red. Z. H. Nowak, współprac. R. Czaja, Torun 2000, s. 14.

${ }^{2}$ J. Tandecki, Podziały administracyjne państwa zakonnego w Prusach, w: Państwo zakonu krzyżackiego w Prusach, s. 17. 
w Ziemi Świętej własne samodzielne państwo, choć pod duchowym zwierzchnictwem Stolicy Apostolskiej.

Podstawowym zbiorem źródeł do badań nad historią Zakonu Krzyżackiego jest Scriptores Rerum Prussicarum zawierające cenne z punktu widzenia niniejszego artykułu kroniki: Kronikę Oliwska opata Stanisława i Kronikę Pruska Piotra $z$ Dusburga. Obie posiadają podstawowe znaczenie dla dziejów Zakonu Krzyżackiego w kontekście stosunków z Polską. Dla badań nad początkami Zakonu ważne są również dokumenty zebrane w dwóch kodeksach: pruskim i Zakonu Najświętszej Marii Niemieckiej. Mniej korzystnie przedstawia się sytuacja w przypadku genezy zakonu w Polsce, ze względu na brak źródeł kronikarskich. Stąd dla jego początków nad Bałtykiem najważniejsze są dokumenty księcia mazowieckiego Konrada, bulle cesarskie i papieskie. Zródła dokumentowe były wielokrotnie interpretowane przez niemieckich i polskich historyków. Do tej dyskusji włączył się Gerard Labuda swoją rozprawą Stosunek prawnopubliczny Zakonu Krzyżackiego do Rzeszy Niemieckiej w świetle Złotej bulli Fryderyka II roku z ro$k u 1226^{3}$. Istotny wkład mają badania Tomasza Jasińskiego, który udowodnił, że bulla cesarska z Rimini została wystawiona w 1235 roku$^{4}$.

Ponownie historycy zajęli się sprawą autentyczności przywileju kruszwickiego księcia Konrada Mazowieckiego, w myśl którego książę pozbawiał się praw władczych do ziemi chełmińskiej, a biskupa Chrystiana wywłaszczał z Prus. Ówczesna rzeczywistość historyczna a treść owego dokumentu w żaden sposób do siebie nie przystają. Wśród niemieckich historyków Max Perlbach ${ }^{5}$ uznał ten dokument za falsyfikat sporządzony w kancelarii wielkiego mistrza Zakonu Krzyżackiego Hermana von Salza. Gerard Labuda jest jednym z tych polskich historyków, którzy zajęli stanowisko zgodne z jego ustaleniami.

W pracach polskich i niemieckich historyków sporne są niekiedy nie tylko podstawowe fakty, ale przede wszystkim sposób ich przedstawiania i interpretacji. Spośród polskich historyków dziejom Zakonu Krzyżackiego w Prusach poświęcili wiele uwagi Gerard Labuda i Marian Biskup. Badania Sławomira Jóźwia$\mathrm{ka}^{6}$ skoncentrowały się na dokonujących się w ciągu dwóch wieków mechanizmach przekształceń jakim podlegał zakon, który z uniwersalistycznej korporacji duchownej przeistoczył się w zwierzchnika powstałego nad Bałtykiem władztwa terytorialnego. Strukturom administracyjnym i kościelnym państwa Zakonu Krzyżackiego w Prusach poświęcona jest praca zbiorowa powstała pod redakcją Zeno-

${ }^{3}$ G. Labuda, Stosunek prawnopubliczny Zakonu Krzyżackiego do Rzeszy Niemieckiej w świetle Ztotej bulli Fryderyka II z roku 1226, w: Tenże, Studia krytyczne o początkach Zakonu Krzyżackiego w Prusach i na Pomorzu, Poznań 2007, s. 55-87.

${ }^{4}$ T. Jasiński, Złota Bulla Fryderyka II dla Zakonu Krzyżackiego z roku rzekomo 1226, „Roczniki Historyczne", 60 (1994) s. 107-153.

${ }^{5}$ M. Perlbach, Zur Kritik des ältesten preussischen Urkunden, w: Tenże, Preussich-polnische Studien zur Geschichte des Mittelalters.H.1, Halle 1886, s. 78-96.

${ }^{6} \mathrm{~S}$. Jóźwiak, Centralne i terytorialne organy władzy zakonu krzyżackiego w Prusach $w$ latach 1228-1410. Rozwój-przeksztatcenia - kompetencje, Torun 2001. 
na Huberta Nowaka ${ }^{7}$. Również starsze prace przedwojennych historyków takich jak: S. Kujot mimo dezaktualizacji niektórych tez pozostają przydatne w badaniach historycznych. Po stronie niemieckiej ważne są prace Hartmuta Boockmanna ${ }^{8}$ oraz Udo Arnolda.

\section{Organizacja zakonu przed jego sprowadzeniem do Prus}

Powstały, w okresie ruchu krucjatowego w Ziemi Świętej, Zakon Szpitala Najświętszej Marii Panny Domu Niemieckiego w Jerozolimie, jako organizacja do walki z poganami otrzymał regułę templariuszy, tj. zespół norm powstały $\mathrm{z}$ udziałem Bernarda $\mathrm{z}$ Clairvaux, natomiast w sprawach opieki nad chorymi regułę joannitów9 .

Zakon Krzyżacki za rządów trzech pierwszych mistrzów ${ }^{10}$ nie odgrywał większej roli militarnej i politycznej. Swój rozwój w znacznym stopniu zawdzięczali Krzyżacy czwartemu wielkiemu mistrzowi Hermanowi von Salza ${ }^{11}$, za rządów którego zakończył się pionierski okres w dziejach zakonu. Również za jego rządów zakon rozpoczął budowę swego państwa zakonnego nad Bałtykiem ${ }^{12}$. Bowiem Herman von Salza poszukiwał dla swego zakonu nowych terenów działania, mianowicie na Półwyspie Bałkańskim, w Siedmiogrodzie i w Prusach ${ }^{13}$.

Struktura wewnętrzna Zakonu Krzyżackiego wykształciła się po akcie z 1198 roku i przetrwała kilka stuleci ${ }^{14}$. Do roku 1221 mowa jest jedynie o ,zwyczajach” - consuetudines, które wymieniał już Innocenty III w 1209 roku, powtarzając przy tym wyrażenia z dokumentu Celestyna III z 1196 roku $^{15}$. Papież Innocenty IV w 1244 roku zezwolił na zmianę niektórych przepisów reguły, przez co powstała wspomniana już przeze mnie wersja statutów, które mimo dodawania późniejszych rozporządzeń zachowały swoją ważność do 1422 roku $^{16}$.

Centralnym gremium decydującym była wielka kapituła, której postanowienia były decydujące dla każdego wielkiego mistrza. Im większy był zasięg teryto-

${ }^{7}$ Państwo zakonu krzyżackiego w Prusach, red. Z. H. Nowak, współprac. R. Czaja, s. 7-13, 14-15, 17-2767-79, 95-99.

${ }^{8}$ H. Boockmann, Zakon Krzyżacki, Gdańsk-Warszawa 2004

${ }^{9}$ Tamże, s. 20.

${ }^{10}$ Trzeci z nich, Heinrich von Tunna, zwany Bartem (1208-1209), został wielkim mistrzem zaledwie w kilka miesięcy po wstąpieniu do zakonu.

${ }^{11}$ K. Górski, Studia i szkice z dziejów Państwa Krzyżackiego, Olsztyn 1986, s. 35; Szerzej pisze o tym w swojej książce E. Caspar, Hermann von Salza und die Gründung des DO-Staats in Preussen, Tübingen 1924.

${ }^{12}$ U. Arnold, Zakon Krzyżacki. Z Ziemi Świętej nad Bałtyk, Toruń 1996, s. 22.

${ }^{13}$ M. Biskup, G. Labuda, Dzieje Zakonu Krzyżackiego w Prusach, Gdańsk 1986, s. 105 i n.

${ }^{14}$ Strukturę tę znamy dzięki przekazom dokumentowym i statutom zakonu. Jak wykazał Sterns obecna wersja statutów powstała przed 1229 roku, zob. U. Arnold, Zakon Krzyżacki. Z Ziemi Świętej nad Battyk, s. 30.

${ }^{15}$ Tamże, s. 30; Tabulae ordinis Theutonici: ex tabularii regii Berolinensis codice potissimum, Berlin 1869, nr 296.

${ }^{16}$ U. Arnold, Zakon Krzyżacki. Z Ziemi Świętej nad Battyk, s. 30. 
rialny Zakonu Krzyżackiego, tym więcej uprawnień musiała przekazać kapituła poszczególnym urzędnikom, głównie średniego szczebla baliwatu. Zwiększał się zakres władzy wielkiego mistrza ${ }^{17}$.

Obok wielkiego mistrza najważniejszymi urzędnikami byli wielki komtur i marszałek. Mieli oni ze sobą ściśle współpracować, a ich wzajemne relacje zależały od faktu, czy był to czas wojny czy pokoju. W czasie pokoju wyższy rangą był wieki komtur, pełniący równocześnie funkcję zastępcy wielkiego mistrza. Jego władzy podlegali wszyscy duchowni oraz świeccy, w tym komtur, zarządzający żywnością zakonu, zbrojownią i wszystkie urzędowe obiekty nie podlegające marszałkowi. Jako nadzorca skarbca zakonnego dysponował jednym z trzech kluczy do skarbca, a także był informowany o wpływach złota i srebra. Zajmował się przydziałem żywności dla szpitala, powoływał lekarza dla chorych zakonników. Podczas podróży komtur prowadził i był odpowiedzialny za cały tabor, $\mathrm{w}$ tym namiot wielkiego mistrza. W wypadku wojny wielki komtur był podporządkowany marszałkowi ${ }^{18}$.

Marszałek był głównie dowódcą podczas walki; wówczas podlegali mu wszyscy dostojnicy zakonni. Do dyspozycji miał wicemarszałka, mógł spośród braci mianować swego zastępcę. Marszałek, a nie mistrz miał do przekazywania rozkazów herolda. To on mianował dowódcę turkopoli, któremu podlegali także sarianci. Podczas pokoju sprawował władzę nad wszystkimi braćmi noszącymi broń, nad uzbrojeniem, kuźnią, siodlarnią, wierzchowcami, zwierzętami pociągowymi. Marszałka zastępował wielki komtur ${ }^{19}$.

Szpitalnik (urząd przejęty od joannitów) stał na czele szpitala, który był utrzymywany w głównej siedzibie zakonu. Bez wątpienia nie podlegało mu całe szpitalnictwo zakonne, gdyż pozostali szpitalnicy podlegali komturom krajowym. Nie podlegały mu szpitale poszczególnych zakonów krzyżackich, firmarie. Podlegał jedynie wielkiemu mistrzowi, a w czasie wojny także marszałkowi ${ }^{20}$.

Szatny wymieniony po raz pierwszy w 1228 roku odpowiadał za komore $\mathrm{z}$ ubraniami zarówno $\mathrm{w}$ życiu codziennym, jak i podczas wojny, gdy podlegał również marszałkowi. Marszałkowi podlegał w czasie pokoju w sprawach uzbrojenia $^{21}$.

Główną kasą Zakonu rozporządzał wymieniony w 1240 roku skarbnik. Z tego tytułu rozporządzał jednym z trzech kluczy do skarbca. Był odbiorcą złota i srebra. Pod koniec każdego miesiąca rozliczał się przed mistrzem lub wielkim komturem i razem z jednym z nich sporządzał rozliczenie, które następnie przedkładał pozostałym dostojnikom. Skarbnik pokrywał z kasy głównej koszty utrzymania

${ }^{17}$ Tamże, s. 34; na przełomie XIII i XIV w. nastąpiło osłabienie pozycji wielkich mistrzów na rzecz mistrzów krajowych Niemiec, Prus i Inflant.

${ }^{18}$ Tamże, s. 35.

${ }^{19}$ Tamże, s. 35. S. Jóźwiak, Centralne i terytorialne organy władzy zakonu krzyżackiego $w$ Prusach w latach 1228-1410, s. 32, 72 i n.; U. Arnold, Zakon Krzyżacki, s. 60-101; Tamże, s. 102-129.

${ }^{20}$ Tamże, s. 35.

${ }^{21}$ Tamże, s. 36. 
mistrza, do czego nie były zobowiązane baliwaty, cieszące się niezależnością finansową. Urząd skarbnika należał do najmłodszych urzędów zakonu ${ }^{22}$.

Urząd kasztelana z Montfort występuje już w 1230 roku, zaraz po zajęciu tej twierdzy przez Krzyżaków. Przyczyną powstania tego urzędu był prawdopodobnie fakt, że zamek ten stał się główną siedzibą zakonu, a ponadto obok Akkonu był drugim ważnym punktem oparcia. Potrzebny był więc stały, lokalny zarządca. Urząd kasztelana został zlikwidowany w 1271 roku, gdy padł zamek w Montfort ${ }^{23}$.

Wyżej wymieni dostojnicy powoływani byli przez wielkiego mistrza, za zgodą wielkiej kapituły. Urzędnicy ci należeli do najbliższych współpracowników wielkiego mistrza i z wyjątkiem kasztelana, tworzyli w Prusach od XIV w. grupę wielkich dostojników ${ }^{24}$.

Obok tych urzędów istniały inne podporządkowane wyżej wymienionym: wicemarszałek i praeceptor minor ${ }^{25}$; były one rozwinięciem istniejących już urzędów marszałka i wielkiego komtura. Były urzędy powoływane wyłącznie w zależności od potrzeb, jak np. komtura zarządzającego żywnością Zakonu Krzyżackiego, zwanego podstolim, czy w późniejszym okresie w Prusach urzędy szafarza, rybickiego, czy mistrza bartnego. Były również urzędy duchowne, jak przeor oraz kapelan polowy, który w czasie wojny odprawiał mszę świętą i godzinki ${ }^{26}$.

Na skutek wzrostu posiadłości poza Ziemią Świętą ukształtowała się w zakonie pionowa struktura władzy. Wielki mistrz wraz z wielką kapitułą obsadzali komturów krajowych w Armenii, Romanii (Grecji), Sycylii, Apulii, w różnych krajach Niemiec, w Austrii, Prusach, Inflantach i Hiszpanii. Komturzy krajowi uważani byli za najważniejszych dostojników, co potwierdzają ich kompetencje. Wewnątrz swoich baliwatów posiadali pozycję podobną do tej, jaką zajmował wielki mistrz wewnątrz całego zakonu. $Z$ czasem przejmowali oni niektóre uprawnienia wielkiego mistrza i dążyli do umocnienia swej pozycji. $Z$ biegiem czasu urząd komtura krajowego Niemiec przekształcił się w urząd mistrza krajowego Niemiec. Zwierzchnikami baliwatów byli komturzy krajowi, którym podlegali poszczególni komturzy stojący na czele komend lub - w Prusach i Inflantach komturstw. Przełożeni szpitali w zależności od ich wielkości, byli nazywani komturami lub zarządcami. Komtur wraz z dwunastoma braćmi tworzyli konwent ${ }^{27}$.

Zarządcy, będący przełożonymi wspólnot mniejszych od konwentów podlegali komturowi. Niższe wspólnoty powstawały w razie potrzeby, głównie w Prusach. Poszczególni urzędnicy cieszyli się szeroką autonomią, która była poddana podwójnej kontroli. Kontrolę sprawowała właściwa kapituła na każdym szczeblu

${ }^{22}$ Tamże, s. 36.

${ }^{23}$ Tamże, s. 36.

${ }^{24}$ K. Górski, Ustrój państwa i Zakonu Krzyżackiego, Gdynia 1938, s. 23.

${ }^{25}$ Jego istnienie potwierdzają dokumenty, Tabulae ordinis Theutonici, $\mathrm{nr}$ 121.; U. Arnold, Zakon Krzyżacki, s. 37.

${ }^{26}$ Tamże, s. 37.

${ }^{27}$ Górski, Studia i szkic z dziejów Państwa Krzyżackiego, s. 42; U. Arnold, Zakon Krzyżacki, s. 38 . 
drabiny urzędniczej oraz niezależnie od tego kontrolę sprawowali przełożeni i ich kapituła. Ten system stanowił przeszkodę na drodze do samowoli ${ }^{28}$.

Razem z zakonem rozwijała się jego struktura, zapewniając mu niezbędne oparcie. Wykształcone w ten sposób struktury wewnętrzne zakonu odpowiadały jego potrzebom i były jak najbardziej aktualne. Kostniała duchowa treść tych struktur, co sprawiało, że Zakon Krzyżacki w późniejszym okresie nie dopasował się do zmienionej sytuacji.

\section{Podstawy terytorialne i ekspansja państwa krzyżackiego w Prusach}

Fundamenty pod budowę państwa krzyżackiego nad Bałtykiem kładł słynny przywilej cesarski z 1226 roku $^{29}$. Cztery lata później przybywający nad Wisłę Krzyżacy rozpoczęli budowę nowego państwa, zależnego początkowo od cesarstwa. Przybył więc do Prus wielki mistrz Herman von Salza wyposażony w prawa książęce: regale monety, targów, prawo ściągania podatków, wydawania ustaw, najwyższego sądownictwa, ceł, myta, rybołówstwa, łowiectwa, górnictwa oraz w pełny immunitet. Dodatkowo papież egzymował Krzyżaków, uznając pruski teren misyjny za część Ojcowizny św. Piotra. Egzempcja dotyczyła jedynie Prus, a później Inflant, natomiast inne posiadłości zakonu zostały wzięte jedynie pod protekcję papieską ${ }^{30}$. Wielki mistrz Gerhard von Malberg złożył w roku 1243 hołd i otrzymał inwestyturę z rąk papieża ${ }^{31}$. Dążący konsekwentnie do usamodzielnienia się wielcy mistrzowie z czasem przestali brać inwestyturę od papieża i płacić czynsz. Nie otrzymywali też inwestytury od cesarzy stając się powoli zupełnie niezależni od obu głównych potęg średniowiecza, co nastąpiło już około połowy XIII w. Krzyżacy tym samym osiągnęli swój cel i stworzyli suwerenne państwo ${ }^{32}$, którego powstanie było rzeczą bez precedensu - według obowiązującej doktryny średniowiecznej mogło albo stanowić część jednej z monarchii świeckich, albo bezpośrednio podlegać papiestwu.

Nim jednak do tego doszło w wyniku prowadzonych przez władzę zakonu pertraktacji z księciem mazowieckim Konradem przybyła w 1228 roku nad Wisłę niewielka grupa Krzyżaków, licząca zaledwie trzech rycerzy pod dowództwem Filipa z Halle i zajęła leżący przy przeprawie wiślanej, gródek Vogelsang ${ }^{33}$. Kilkuletnie rokowania Konrad mazowiecki sfinalizował w 1230 roku nadając Krzy-

${ }^{28}$ Tamże, s. 39.

${ }^{29}$ Dokument ten od miejsca wystawienia i uroczystego opatrzenia pieczęcią zwany jest złota bulla z Rimini. Codex diplomaticus Ordinis Sancte Marie Theutonicorum, Urkundenbuch zur Geschichte Des Deutschen Ordens, Mainz 1845, s. 75-78.

${ }^{30}$ Preußisches Urkundenbuch (dalej: Pr. Ub.), hrsg. V. R. Phillippi [i in.], Bd. I, KönigsbergMarburg 1882, nr 108.

${ }^{31}$ Labuda, Studia krytyczne o początkach Zakonu Krzyżackiego w Prusach i na Pomorzu, s. 47.

${ }^{32}$ Wprawdzie w późniejszym okresie papież Jan XXII w roku 1317 domagał się od Krzyżaków świętopietrza, ale szybko zaniechał tego zamiaru. Biskup, Labuda, Dzieje Zakonu Krzyżackiego w Prusach, s. 344.

${ }^{33}$ Cz. Frankiewicz, Historia Pomorza w zarysie, Toruń 1927, s. 29. 
żakom ziemię chełmińską mającą stanowić bazę terytorialną ich działalności na terenie Prus ${ }^{34}$. Wiosną 1230 roku przybył z większą grupą rycerzy zakonnych Herman von Balk, późniejszy mistrz krajowy Prus ${ }^{35}$. Krzyżacy przystąpili do opanowywania zajętej częściowo przez Prusów ziemi chełmińskiej. W 1231 roku niewielka grupa rycerzy zakonnych przekroczyła Wisłę i na przeciwległym brzegu założyła prowizoryczną bazę pod nazwą Thorn (Toruń) prawdopodobnie na pamiątkę zamku zakonnego Toron $\mathrm{w}$ Palestynie ${ }^{36}$. Z pomocą krzyżowców z Niemiec, Polski i Pomorza udało się zakonowi w latach 1231-1233 całkowicie wyprzeć Prusów z ziemi chełmińskiej. Na wiele lat stolicą mistrza krajowego pruskiego Hermana von Balka i jego następców na tym urzędzie stało się Chełmno, dokąd przeniesiono z Torunia siedzibę zakonu. Właściwy podbój ziem rdzennie pruskich, leżących na północ od Osy rozpoczął się pod koniec 1234 roku. Krzyżacy posuwali się wzdłuż Wisły, a potem wzdłuż wybrzeża pruskiego, przy czym najważniejsze etapy tego podboju wyznaczają daty założenia grodów krzyżackich.

Zanim jednak przystąpiono do systematycznego podboju Prus doszło do zasadniczej zmiany w stosunkach między Zakonem Krzyżackim a biskupem pruskim Chrystianem podejmującym próby utworzenia własnego państwa biskupiego. W roku 1231 zawarł układ z Krzyżakami przyznający mu dwie trzecie terytorium, które miało zostać zdobyte, co oznacza, że uznawał się za władcę nowego obszaru $^{37}$. Do otwartego konfliktu jednak nie doszło, głównie chyba dlatego, że biskup Chrystian podczas wyprawy misyjnej na Sambię popadł w niewolę, w której przebywał do 1238 roku $^{38}$. Jego nieobecność wykorzystał zakon do przejęcia Prus w całkowite władanie przedstawiając papieżowi układ kruszwicki, zawierający sfałszowaną formułę nadania Krzyżakom całych Prus i na tej podstawie zażądał przekazania im tej ziemi na własność. Papież Grzegorz IX w dokumencie z Rieti, nie odwołując się bezpośrednio do nadania Konrada, przejął Prusy na własność i jako taką przekazał z kolei zakonowi na wieczne posiadanie ${ }^{39}$. Biskup Chrystian po powrocie z niewoli zaskarżył Zakon Krzyżacki na dworze papieskim próbując $\mathrm{w}$ ten sposób zmienić sytuację. Próba ta nie odniosła skutku, papież 30 VII 1243 roku utworzył osobne biskupstwo w ziemi chełmińskiej oraz trzy diecezje w Prusach: pomezańską, warmińską i sambijską ${ }^{40}$. Ponadto zarządził, że

${ }^{34}$ Treść tego dokumentu wciąż budzi kontrowersje. Labuda, Biskup, Dzieje Zakonu Krzyżackiego w Prusach, s. 118 i n.

${ }^{35}$ Grupa ta licząca według Piotra z Duisburga siedem osób zajęła oddany im przez Konrada mazowieckiego gród w Nieszawie. Petri de Dusburg, Chronicon Terre Prussiae, hrsg. v. M. Töppen, w: Scriptores rerum Prussicarum, hrsg. v. T. Hirsch, M. Töppen, E. Strehlke, Bd. I, Leipzig 1861, lib. II, c. 11, s. 47 i lib. III, c. 3, s. 52; kronikarz liczbę 7 rycerzy wymienia dwukrotnie, przy czym na 1 rycerza przypadało około 10 giermków i pachołków.

${ }^{36}$ Boockmann, Zakon Krzyżacki, s. 69.

${ }^{37}$ Biskup, Labuda, Dzieje Zakonu Krzyżackiego w Prusach, s. 124; Pr. Ub., Bd. 1, nr 83, s 64.

${ }^{38}$ Biskup, Labuda, Dzieje Zakonu Krzyżackiego w Prusach, s. 125.

${ }^{39}$ Pr. Ub., Bd. I, nr 108.

${ }^{40}$ Biskup, Labuda, Dzieje Zakonu Krzyżackiego w Prusach, s. 164-165; papież oparł się na przygotowanym przez legata Wilhelma z Modeny podziale Prus. Pr.Ub., Bd. I, nr 143, 144, 152. 
biskupi mają odtąd posiadać jedną trzecią część kraju, a zakon jako dźwigający główny ciężar walki z poganami dwie trzecie części kraju. Chrystian nie przyjął proponowanej mu jednej spośród czterech nowo tworzonych diecezji. Spór zakończyła jego śmierć w 1244 roku. Krzyżakom udało się w przyszłości obsadzić biskupstwa pomezańskie i sambijskie własnymi kapłanami zakonnymi, co umożliwiło im podporządkowanie sobie całego ich uposażenia w ziemi. Jedynie biskup warmiński utrzymał autonomię majątkową. Krzyżacy odnieśli jeszcze jeden sukces doprowadzając, za zgodą biskupa płockiego Guntera do połączenia w 1235 roku własnego zakonu z zakonem „Rycerzy Chrystusowych” w Dobrzyniu. Potwierdzenie faktu unifikacji obu zakonów znajduje się w bulli papieża Grzegorza $I^{41}$. Tym samym Zakon Krzyżacki przejął wszystkie posiadłości „Rycerzy Chrystusowych" jakie otrzymali od Konrada Mazowieckiego. Na skutek protestu tego ostatniego spór rozstrzygnął legat Wilhelm z Modeny przyznając księciu mazowieckiemu Dobrzyń ${ }^{42}$. Zachowywał jednak książę mazowiecki Konrad tytuł fundatora ziemi chełmińskiej, tym samym ziemia ta nadal pozostawała w obrębie patrymonium dynastii Piastów ${ }^{43}$.

Poza działaniami dyplomatycznymi Krzyżacy rozpoczęli działania wojenne w 1234 roku, które z małymi przerwami trwały do roku 1283. Krótko po rozpoczęciu podboju Prus Zakon Krzyżacki w 1237. połączył swe siły z inflanckim zakonem Kawalerów Mieczowych ${ }^{44}$. W pierwszej wielkiej wyprawie krzyżowej na Prusów wzięło udział również rycerstwo niemieckie, a głównego kontyngentu dostarczyły oddziały książąt: Konrada Mazowieckiego i Kazimierza Kujawskiego, księcia wrocławskiego Henryka Brodatego, oraz książąt Pomorza Gdańskiego Swiętopełka i Sambora ${ }^{45}$. Decydująca bitwa rozegrała się nad rzeką Dzierzgonia (Prus. Sirgune). Prusowie pomezańscy zostali pobici, a do zwycięstwa wojsk krzyżowych przyczyniły się w dużej mierze oddziały pomorskie ${ }^{46}$. Zdobyty został wówczas Kwidzyn, który stał się głównym punktem służącym do opanowania Pomezanii. W pierwszej kolejności zaatakowane zostały ziemie Pomezanii, Pogezanii i Warmii. Krzyżakom w opanowaniu tych terenów dopomogły wyprawy

${ }^{41}$ Przy okazji unifikacji obu zakonów biskup płocki wystawił odpowiedni dokument, który zaginął, lecz wzmianka o nim znalazła się w potwierdzającej fakt połączenia się obu zakonów bulli papieża Grzegorza IX, por. Pr. Ub., nr 118, s. 90.

${ }^{42} \mathrm{~W}$ zamian musiał zrzec się czterech posiadłości koło Nieszawy, wykupić wszystkie uprawnienia jakie ktokolwiek z jego rycerzy posiadał jeszcze w ziemi chełmińskiej oraz zobowiązał się zapłacić 150 grzywien srebra. Pr. Ub., Bd. I, 119, s. 90.

${ }^{43}$ Swój stosunek nadrzędny do zakonu „Rycerzy Chrystusowych” określił książę Konrad Mazowiecki pojęciem: ius patronatus; por. Pr. Ub., Bd. I, nr 126, s. 95; M. Biskup, G. Labuda, Dzieje, s. 121, 129-130; por. także: G. Labuda, Stanowisko ziemi chetmińskiej w państwie krzyżackim w latach 1228-1454, „Przegląd Historyczny”, 45, 1954, s. 302.

${ }^{44}$ Pierwszym mistrzem inflanckim został Herman von Balk, dotychczasowy mistrz pruski. J. Żenkiewicz, Litwa na przestrzeni wieków i jej powiązania z Polska, Toruń 2001, s. 24; Jóźwiak, Centralne i terytorialne organy władzy zakonu krzyżackiego w Prusach, s. 23.

${ }^{45}$ Biskup, Labuda, Dzieje Zakonu Krzyżackiego w Prusach, s. 140; Frankiewicz, Historia Pomorza $w$ zarysie, s. 31. Podana przez niego data bitwy jest błędna; Henryk Brodaty został przez niego mylnie oznaczony jako Henryk Pobożny.

${ }^{46}$ Petri de Dusburg, Chronicon, lib. III, c. 11, s. 53. 
krzyżowe księcia saskiego Ottona z Brunszwiku i margrabiego miśnieńskiego Henryka $^{47}$, z pomocą którego zdobyto okolice jeziora Druso (Drużno), Krzyżacy ponadto zajęli siedzibę biskupa Chrystiana Zantyr oraz zbudowali grody w Elblągu (1237) ${ }^{48}$ i w Dzierzgoniu (1238) ${ }^{49}$. Po wycofaniu się margrabiego Henryka oddziały krzyżackie zdobyły jeszcze warmiński gród Bałgę, który plemiona Pomezanów, Warmów, Natangów i Bartów bezskutecznie próbowały zdobyćs ${ }^{50}$. Krzyżakom przybył z odsieczą w 1239 roku książę saski, Otto z Brunszwiku, który przebywając przez cały rok w Warmii, w dużej mierze przyczynił się do ujarzmienia okolicznych plemion pruskich ${ }^{51}$.

Krzyżacy wzdłuż Mierzei Wiślanej dotarli w 1240 roku do Sambii. Jednocześnie poczynili pierwsze kroki celem jej opanowania. Dalszą ekspansję zmierzającą w kierunku Inflant przerwało wielkie powstanie podbitych plemion: Pomezanów, Pogezanów, Warmów, Natangów i Bartów w 1242 roku $^{52}$. W tym konflikcie poparł Prusów książę gdański Świętopełk będący do niedawna gorącym zwolennikiem i wiernym sojusznikiem Zakonu ${ }^{53}$. W toku walk spustoszona została ziemia chełmińska, Krzyżakom jednak udało się utrzymać grody. Na pomoc zakonowi przybyły do Prus poważne siły krzyżowców, w tym oddziały księcia austriackiego Fryderyka i księcia Henryka z Lichtensteinu w roku $1246^{54}$. Po kilku początkowych sukcesach Świętopełk uległ połączonym siłom krzyżackim i kujawsko-mazowieckim. Jesienią 1247 roku został zawarty rozejm na Kowalowym Ostrowie pod Świeciem. W myśl rozejmu granica między Pomorzem Gdańskim a Prusami miała biec środkiem Wisły, a w jej delcie środkiem Żuław, biegiem rzeki Tui. Świętopełk w zamian za należący do niego gród Pień (ziemia chełmińska) miał otrzymać ziemię Lanzanię nad morzem. Ostateczny pokój został zawarty rok później (1248) pod naciskiem legata papieskiego, Jakuba z Leodium. Świętopełk zrzekł się swoich posiadłości w ziemi chełmińskiej i na Żuławach, zapewnił swobodne przejazdy dla żeglugi krzyżackiej, zrezygnował z pobierania od Krzyżaków cła, z wyjątkiem przystani gdańskiej, oraz zwrócił gród w Zantyrze. Krzyżacy w zamian oddali mu syna Mściwoja ${ }^{55}$, którego Świętopełk dał jako poręczenie pokoju w zakład. Ten pokój oznaczał całkowitą klęskę Świętopełka. Warto przy tym zauważyć, że walki z księciem gdańskim Świętopełkiem otwierają nowy etap wojen Krzyżaków nad Bałtykiem, którzy do tej pory walczy-

\footnotetext{
49. i kultura Hanzy, Warszawa 1995, s. 26.

${ }^{49}$ Biskup, Labuda, Dzieje Zakonu Krzyżackiego w Prusach, s. 140 i n.

${ }^{50}$ Tamże, s. 141.

${ }^{51}$ Petri de Dusburg, Chronicon, lib. III, cap. 25-27, s. 63-65.

${ }^{52}$ Biskup, Labuda, Dzieje Zakonu Krzyżackiego w Prusach, s. 143.

${ }^{53}$ Pr. Ub., Bd. I, 130.

${ }^{54}$ Biskup, Labuda, Dzieje Zakonu Krzyżackiego w Prusach, s. 155.

${ }^{55}$ Oba dokumenty: Pr. Ub., Bd. I, 194, 213.
}

${ }^{47}$ Labuda, Studia krytyczne o początkach Zakonu Krzyżackiego w Prusach i na Pomorzu, s. 48-

${ }^{48} \mathrm{~W}$ Elblągu osiedlili się mieszczanie z Lubeki, dając początek miastu na prawie lubeckim, które z czasem przejęło rolę dawnego ośrodka miejskiego Prusów, Truso. J. Schildhauer, Dzieje 
li oficjalnie tylko przeciw pogańskim Prusom. Natomiast teraz wystąpili przeciw jednemu z władców chrześcijańskich.

W niedługim czasie pod bezpośrednim nadzorem legata papieskiego Jakuba z Leodium został zawarty drugi układ. Pokój dzierzgoński ${ }^{56}$ z 7 II 1249 roku regulował sporne sprawy między Zakonem Krzyżackim a Prusami. Ludność Pomezanii w zamian za uznanie władzy zwierzchniej zakonu miała zachować wolność osobistą, pod warunkiem jednak, że nie odstąpi od wiary chrześcijańskiej. Układ gwarantował wiele swobód i uprawnień o charakterze majątkowym i prawnym. Umowa dzierzgońska zyskała z czasem duże znaczenie w życiu ustrojowym Prus. Jej przepisy stały się wzorem do regulowania stosunków z innymi plemionami pruskimi w miarę ich podboju.

Kolejnym celem podbojów krzyżackich stała się Sambia. Poprzez zajęcie Sambii Krzyżacy pragnęli zapewnić sobie bezpośrednią komunikację między Prusami i Inflantami. Zewnętrznym wyrazem tych dążeń było ponowne złączenie godności mistrza krajowego obu krzyżackich kolonii w ręku Dytryka von Grüningen $(1246-1259)^{57}$.

Zakon Krzyżacki w roku 1250 zorganizował koalicję z książętami ruskimi, do której przyłączyli się Jaćwięgowie ${ }^{58}$. Była ona skierowana przeciwko litewskiemu księciu Mendogowi. Zagrożony władca litewski zawarł z Krzyżakami ugodę i uzyskawszy również poparcie papieskie przyjął chrzest i koronował się na króla Litwy.

Do Prus w latach 1250-1251 przybyły z Niemiec nowe oddziały krzyżowców przyprowadzone przez margrabiego brandenburskiego Ottona, oraz biskupa merseburskiego Henryka i hrabiego Henryka ze Szwarzburga ${ }^{59}$. Z ich pomocą zakon przystąpił do ostatecznej rozprawy z niepodległymi dotąd mieszkańcami południowej Natangii i leżącej w głębi kraju Barcji. Do walk tych wmieszał się książę gdański Świętopełk. W odpowiedzi na jego wyprawę odwetową do Pomezanii ${ }^{60}$ Zakon Krzyżacki w roku 1252 dotarł pod Oliwę pustosząc klasztor ${ }^{61}$. W następnym roku został zawarty pokój na warunkach ustalonych w 1248 roku.

W 1253 roku Krzyżacy pod wodzą wielkiego mistrza dokonali podboju Galindii. Po czym zakon ponownie zorganizował ekspedycję przeciwko Sambii, która od samego początku stanowiła jeden z głównych celów krzyżackiej ekspansji. Tym razem z wielką wyprawą krzyżową przybył do Prus, król czeski, Przemysł Otokar II ${ }^{62}$. Po drodze przyłączył się do tej wyprawy margrabia brandenburski Otton. Podczas wyprawy zbudowano nad rzeką Pregołą gród, który na cześć Prze-

\footnotetext{
${ }^{56}$ Pr. Ub., Bd. I, 218; na znaczenie tego układu zwrócił uwagę W. Kętrzyński, Oludności polskiej w Prusach krzyżackich, Lwów 1882, s. 283 i n.

${ }^{57}$ Biskup, Labuda, Dzieje Zakonu Krzyżackiego w Prusach, s. 147.

${ }^{58}$ Tamże, s. 148.

${ }^{59}$ Tamże, s. 148.

${ }^{60}$ O najeździe Świętopełka na Pomezanię zob. Pr. Ub., Bd. I, 25.

${ }^{61}$ Zob. w Kronika Oliwska, w: Scriptores rerum Prussicarum, Bd. I, s. 683; Bd. 5, s. 600; S. Kujot, Dzieje Prus Królewskich, „Roczniki Towarzystwa Naukowego w Toruniu”, 1913-1924, cz. 2, s. $746 \mathrm{i}$ in.

${ }^{62}$ Petri de Dusburg, Chronicon, lib. III, cap. 70, 71, s. 90-92.
} 
mysła II został nazwany Königsberg, tj. Góra Królewska (Królewiec, ob. Kaliningrad). Zbudowano u ujścia rzeki Daugi drugi ważny port - Kłajpedę (niem. Memel) tworząc $w$ ten sposób korytarz między Prusami a Inflantami. Oba grody stały się głównymi punktami krzyżackiego panowania w tym rejonie ${ }^{63}$. Sambia ostatecznie została opanowana w 1255 roku. Wprawdzie zajęcie przez Krzyżaków Półwyspu Sambijskiego stworzyło upragniony korytarz, lecz nie zapewniało Krzyżakom bezpiecznego przejścia, dopóki z sąsiednich terenów groziły wrogie napady. W tej sytuacji zakon postanowił podporządkować sobie Żmudź. Odpowiedzią Żmudzinów na krzyżackie plany była nieudana próba opanowania Kłajpedy. W wyniku tej akcji spustoszone zostały ziemie podbitych przez Zakon Krzyżacki Kurów. Odpowiedzią była wyprawa krzyżacka na Żmudź. Układ sił zaczął się zmieniać na niekorzyść Krzyżaków, gdy król Litwy, Mendog (12531263) zerwał dotychczasowy sojusz. Do decydującej bitwy doszło w dniu 13 VII 1260 roku pod Durbą, w pobliżu Libawy. Połączone siły żmudzko-litewskie w bitwie pod Durbą rozgromiły wojska Krzyżaków pruskich i inflanckich. Była to jedna z największych klęsk, jakich Zakon Krzyżacki doznał w tym czasie. Polegli obaj wodzowie krzyżaccy, a wraz z nimi 150 rycerzy ${ }^{64}$.

Wcześniejsze niepowodzenia i klęska Krzyżaków pod Durbą wywołały w 1260 roku wielkie powstanie ludności pruskiej ${ }^{65}$. Swym zasięgiem powstanie objęło wszystkie plemiona - z wyjątkiem Pomezanii, zamieszkałe między Wisłą a Niemnem. Powstanie nie miało jednego przywódcy, lecz każde plemię obrało własnego wodza: Sambom przewodził Glande, Natangom - Monte, Bartom - Dziwan, Warmom - Glape, Pogezanom - Autume, Jaćwięgom - Skumand. Pierwsze uderzenie powstańców pruskich przyniosło im liczne sukcesy. Udało się zbuntowanym plemionom zdobyć i zniszczyć kilka krzyżackich grodów. Jeden z najsłynniejszych wodzów powstania, przywódca Natangów Henryk Monte w roku 1263 wpadł do ziemi chełmińskiej, rozbijając pod Lubawą wojsko mistrza krajowego Helmericha. W walce poległ, wówczas sam mistrz i 40 braci zakonnych. Dowodzony przez Skumanda oddział Jaćwięgów dotarł, aż pod Toruń, podczas gdy inny oddział wdarł się do Pomezanii i zniszczył Kwidzyn (ocalał tylko gród). W rękach Krzyżackich pozostały jedynie grody położone nad Zalewem Wiślanym, jak Welawa, Królewiec, Bałga i Elbląg. Po początkowych sukcesach zakon zaczął odzyskiwać utracone tereny. Nie bez znaczenia była śmierć zamordowanego w 1263 roku króla Mendoga, głównego sojusznika powstańców, a w wkrótce potem jego następcy Trojnata. Litwa pogrążyła się w wewnętrznym chaosie ${ }^{66}$.

Szala zwycięstwa na stronę Krzyżaków zaczęła się przechylać od 1265 roku. Przede wszystkim wojska powstańcze nie potrafiły zdobyć umocnionych grodów, będących bazami wypadowymi wojsk krzyżackich. Ponadto do Prus na wezwanie krucjatowe papieża Klemensa IV przybyli ze znacznymi siłami wojskowymi książę brunszwicki, Albert I, i landgraf Turyngii, Albert II. Ich ojcowie walczyli w Prusach w pierwszym etapie podboju tego kraju przez Krzyżaków, a teraz z po-

\footnotetext{
${ }^{63}$ Biskup, Labuda, Dzieje Zakonu Krzyżackiego w Prusach, s. 153.

${ }^{64}$ Tamże, s. 180.

${ }^{65}$ Żenkiewicz, Litwa na przestrzeni wieków i jej powiązania z Polska, s. 25.

${ }^{66}$ Tamże, s. 26.
} 
mocą zakonowi spieszyli ich synowie. W następnym roku dołączył do krzyżowców margrabia brandenburski, Otto III, a na przełomie 1267/1268 ponownie przybył do Prus król czeski, Przemysł Ottokar ${ }^{67}$. Wojna przybrała charakter podjazdowy. Walczono zaciekle, niszcząc, paląc i grabiąc. W walkach padli przywódcy: Bartów - Dziwan, zwany Niedźwiedziem (1271), Natangów - Monte i Warmów - Glape, obaj w 1272 roku. O zwycięstwie Krzyżaków zadecydowała wielka wyprawa w roku 1272 margrabiego miśnieńskiego, Dytryka II, który spustoszył Natangię. Krzyżacy w roku 1274 ponownie zajęli Lidzbark, ustały walki w okręgach nadmorskich. Opór stawiały jedynie plemiona graniczące z Litwą: Skalowowie, Nadrowowie i Jaćwięgowie (Sudawowie) ${ }^{68}$.

W efekcie trwającego czternaście lat drugiego powstania Prusowie zostali ostatecznie spacyfikowani w 1274 roku $^{69}$. W następnych latach Zakon przystąpił do podboju terenów, które przed wybuchem powstania nie znajdowały się jeszcze w rękach Zakonu Krzyżackiego. Jako pierwsze Krzyżacy zaatakowali plemiona Nadrowów i Skalowów, których opór zakończył się wraz ze zdobyciem przez Krzyżaków ich głównych grodów: Kamswiku i Ragnety $(1275-1276)^{70}$. Na polu walki pozostali Jaćwięgowie, lecz gdy Krzyżacy uporali się z plemionami Prus północnych przystąpili do systematycznego podboju ich ziem. Także i tutaj toczące się w latach $1279-1283$ walki polegały przede wszystkim na mordowaniu i pustoszeniu ${ }^{71}$. Podbój ziemi jaćwięskiej możemy uznać za zakończony w 1283 roku, gdy Krzyżacy dotarli do linii Niemna i zatrzymali się na zachodniej granicy Litwy. Tym samym Krzyżacy umocnili swe panowanie w całych Prusach. Dalszym celem ich ekspansji będą odtąd Pomorze i Litwa. Piotr Dusburg w swej

${ }^{67}$ S. Kujot, Dzieje Prus Królewskich. Do roku 1309, Torun 1914, s. 927.

${ }^{68}$ G. Labuda, Studia krytyczne o poczatkach Zakonu Krzyżackiego w Prusach i na Pomorzu, s. 50.

${ }^{69}$ Boockmanna, Zakon Krzyżacki, s. 74.

${ }^{70}$ Biskup, Labuda, Dzieje Zakonu Krzyżackiego w Prusach, s. 182-183..

${ }^{71} \mathrm{~W}$ opisie Piotra z Dusburga wygląda to następująco: „Krzyżacy niszczyli jeden po drugim okręgi grodowe, równając $\mathrm{z}$ ziemią siedziby, uprowadzając $\mathrm{w}$ niewolę kobiety i dzieci, a mordując wszystkich mężczyzn, którzy usiłowali bronić kraju". Cała ks. III kroniki Piotra z Dusburga zawiera wiele opisów takich spustoszeń, mordów i podpaleń. Frater Theodoricus advocatus Sambiensis de mandato magistri ducens secum plures fratres et mille viros, qui in impugnacionibus municionum fuerunt plenius exercitati, venit navigio ad terram Scalowitarum, que sita est in utroque littore Memele, et accedens improvise ad castrum, situm tunc in eo loco, ubi nunc est castrum Raganita, incepit ipsum impugnare. Quidam scalis positis ad menia nitebantur ascendere. Sed cum Scalowite ex adverso se opponere vellent, sagittarii fratrum per crebra jacula ipsos repulerunt. Violenter igitur illis intrantibus per menia, aliis per portam castri, totam illam multitudinem infidelium, qui plures fuerunt in castro, quam fratrum exercitus continebat, in ore gladii extinxerunt, mulieres et parvulos cum maxima preda rerum aliarum secum ducentes. Hoc facto castrum et suburbium eius et alia edeficia, que in vicino fuerunt, combusserunt.; Petri de Dusburg, Chronicon, lib. III, cap. 182, s. 133. 
kronice pod rokiem 1283 tak pisze: „Kończy się wojna z Prusami, zaczyna się wojna z Litwinami"'72.

Zakon Krzyżacki zakończył podbój Prus osiem lat przed upadkiem Akki i stworzył nad Bałtykiem silną bazę, dzięki której przeżył kryzys, jaki po upadku Królestwa JerozolimskiegoprzeżywaływszystkiezakonyrycerskiedziałającewZiemi Świętej. Trwający ponad 50 lat podbój rozległego terytorium pruskiego był niewątpliwie sukcesem militarnym Krzyżaków. Prusowie mimo znacznej przewagi liczebnej ${ }^{73}$ ulegli najeźdźcy górującemu nad nimi lepszą organizacją wojskową, uzbrojeniem, wyszkoleniem bojowym i taktyką. Mimo posiadanej początkowo ogromnej przewagi liczebnej Prusowie nie potrafili tego faktu wykorzystać. Powodem był brak politycznej jedności znacznie utrudniający działanie militarne poszczególnych ziem. Prusowie nie wykształcili ustroju monarchicznego, lecz utrzymywał się u nich nadal ustrój wiecowy. Stąd plemiona pruskie i jaćwięskie stawały do walki najczęściej pojedynczo. Wyjątek stanowiło wielkie powstanie Prusów, ale i w tym wypadku ujemną stroną był brak jednolitego przywództwa, bowiem każde plemię miało swojego dowódcę ${ }^{74}$. Wojska zakonne w podboju Prus wspomagały silne oddziały krzyżowe. Pomoc wojskowa feudałów i rycerstwa niemieckiego ${ }^{75}$ nie ustawała do zakończenia podboju Prus. Wprawdzie krzyżowcy przybywali do Prus już za czasów biskupa Chrystiana, ale dopiero Krzyżacy potrafili tę pomoc właściwie zorganizować i sprawnie nią pokierować. Udział krzyżowców w dużym stopniu przyczynił się do podboju Prusów. Według Gerarda Labudy opanowanie Prus to tylko jedno z ogniw zaplanowanej na szeroką skalę ekspansji gospodarczej i militarnej żywiołu niemieckiego w Europie Środkowej i Północnej, dlatego też plemiona pruskie stojące na niższym szczeblu rozwoju gospodarczego i politycznego nie były w stanie się temu przeciwstawić ${ }^{76}$.

\section{Organizacja państwa krzyżackiego w Prusach}

Stworzone przez Krzyżaków w Prusach państwo miało charakter teokratyczny i feudalny ${ }^{77}$, oraz podlegało władzy Zakonu jako korporacji duchowej, podle-

${ }^{72}$ Explicit bellum Prussiae Incipit bellum Lethowinorum; Petri de Dusburg, Chronicon..., lib. III, cap. 221, s. 146.

${ }^{73}$ Według G. Labudy liczebność Prusów określa się na przełomie XII i XIII w. na 170 tys. osób, co dawało przeciętnie około 17 tys. wojów, podczas gdy Krzyżaków pod bronią mogło stanąć łącznie z giermkami od 500 do 1000 rycerzy: zob. Biskup, Labuda, Dzieje Zakonu Krzyżackiego w Prusach, s. 158 i n.

${ }^{74}$ Kujot, Dzieje Prus Królewskich, s. 918.

${ }^{75}$ Piotr z Dusburga dostarcza wiele takich przykładów: Petri de Dusburg, Chronicon, cap. 13, $25,27,34,45,52,55,57,59,63,67,71$.

${ }^{76}$ Labuda, Studia krytyczne o początkach Zakonu Krzyżackiego w Prusach i na Pomorzu, s. 53.

${ }^{77}$ Według G. Labudy państwo krzyżackie w Prusach miało charakter feudalny, M. Biskup, G. Labuda, Dzieje, s. 202 i n.; natomiast zdaniem K. Górskiego Krzyżacy nie wprowadzili feudalizmu do Prus, a „Prusy są jedynym krajem, rządzonym przez Niemców, gdzie ustrój ten nie występował”, zob. Górski, Studia i szkice z dziejów Państwa Krzyżackiego, s. 63. 
głej papiestwu. Organizacja państwa krzyżackiego opierała się na zasadzie monarchicznej. Najwyższą władzę w zakonie sprawował dożywotnio wybierany wielki mistrz. Wybierany był przez kapitułę generalną złożoną początkowo z 6, a później 7 mistrzów krajowych i wyższych dostojników z otoczenia wielkiego mistrza. Stale towarzyszył mu tzw. kompan ${ }^{78}$. Wielki mistrz nie posiadał w stosunku do władców świeckich sprawności lennej. Prawo lenne w Prusach pojawia się u schyłku istnienia państwa zakonnego. Wielki mistrz sprawował również władzę zwierzchnią nad Prusami, które były oddzielną prowincją. Przed połową lat sześćdziesiątych XIII w. wielcy mistrzowie utracili prawo sprawowania bezpośredniej władzy w baliwatach przy pomocy wysyłanych do Europy specjalnych wysłanników. Wprawdzie w myśl sformułowanych wówczas Zwyczajów pozostawiono im prawo usuwania nieudolnych mistrzów krajowych, ale nie mogli już mianować swoich wysłanników, którzy przejmowaliby na okres tymczasowy kompetencje zwierzchników prowincji ${ }^{79}$. W Prusach bezpośrednim przedstawicielem wielkiego mistrza był mistrz krajowy, a jego zastępcą był wicemistrz krajowy. Do kompetencji mistrza krajowego należało wysyłanie na podległym im terytorium wizytatorów, mianowanie swoich zastępców na okres tymczasowy, lub „stałego opuszczenia administrowanej przez nich prowincji" ${ }^{80}$. Mieli prawo zakładać nowe jednostki zarządu terytorialnego, kierowali akcją militarną, wydawali polecenie budowy warowni ${ }^{81}$, wraz z kapitułą domu głównego decydowali o obsadzie niższych urzędów. Mistrzowie krajowi zawierali układy z książętami polskimi, z władzami kościelnymi, wystawiali dokumenty lokacyjne ${ }^{82}$ oraz mieli obowiązek przed 1309 roku uczestniczenia w generalnych kapitułach zakonu w Ziemi Świętej i w Europie, głównie w kapitułach wybierających nowego wielkiego mistrza ${ }^{83}$. Komtur krajowy rezydował w Chełmnie. Warto zaznaczyć, że do roku 1288 tylko mistrz krajowy miał prawo czynić nadania ziemi, a komturowie i marszałek krajowy rezydujący w Królewcu czynili to jedynie z upoważnienia mistrza. W Prusach powstała nie znana statutom rada wielkich dostojników zakonu, składająca się z najwyższych urzędników, jak wielki komtur, wielki marsza-

${ }^{78}$ S. M. Kuczyński, Wielka wojna z Zakonem Krzyżackim w latach 1409-1411, Warszawa 1980, s. 68.

${ }^{79}$ Die Statuten des Deutschen Ordens nach den ältesten Hnadschriften (dalej: Statuten), hrsg. V. M. Perlbach, Halle 1890, s. 100-101; od tego czasu pełnomocnicy wielkich mistrzów nie pojawili się więcej na terenie Prus i Inflant. S. Jóźwiak, Centralne i terytorialne organy władzy zakonu krzyżackiego $w$ Prusach w latach 1228-1410, s. 37 i p. 93 s. 37.

${ }^{80}$ Zakres kompetencji wicemistrza krajowego nie odbiegał zapewne od przysługujących ich zwierzchnikom. Zastępcami mistrzów krajowych w Prusach byli: marszałkowie oraz komturzy: trzykrotnie komtur królewiecki, ziemi chełmińskiej, dzierzgoński i podobno elbląski. Jóźwiak, Centralne i terytorialne organy władzy zakonu krzyżackiego w Prusach, s. 34, 44-45.

${ }^{81}$ Petri de Dusburg, Chronicon, s. 89, 131 i 144.

${ }^{82}$ Od lat sześćdziesiątych XIII w. nie byli wyłącznymi wystawcami dokumentów lokacyjnych. Wystawiane były również przed rokiem 1309 przez komturów: malborskich, królewieckich, dzierzgońskich, ziemi chełmińskiej, bałgijskich, elbląskich oraz jednorazowo przez zantyrskiego komtura domowego. Jóźwiak, Centralne i terytorialne organy władzy zakonu krzyżackiego w Prusach, s. 34 i p. 80 s. 34 .

${ }^{83}$ Statuten, s. 91. 
łek, wielki szatny, wielki szpitalnik, wielki podskarbi ${ }^{84}$. Powstała na zasadzie raz dokonanego faktu, w przyszłości rada ta rozszerzała się i wchodzili do niej niektórzy komturowie, lecz bliżej nie znamy składu tej drugiej rady. Wiadomo, jednak, że obie powoli, od schyłku XIV w. ograniczały władzę wielkiego mistrza ${ }^{85}$.

Podstawową samodzielną jednostką było komturstwo. Wzorzec podziału terytorialnego został przeniesiony z krajów śródziemnomorskich, głównie jednak $\mathrm{z}$ ziem niemieckich, gdzie posiadłości Zakonu podzielono na okręgi terytorialne zwane baliwatami lub komturstwami. Zachodziła jednak zasadnicza różnica między komturstwem śródziemnomorskim i zachodnioeuropejskimi, a tymi uksztaltowanymi na ziemi chełmińskiej i w Prusach. Posiadłości zakonu w Prusach tworzyły zwartą strukturę, tam były rozproszone. Wielki mistrz Herman von Salza pragnął utworzyć swoje władztwo na wzór tych posiadanych przez książąt Rzeszy $^{86}$. Krzyżacy po raz pierwszy próbę budowy takiego władztwa podjęli na Węgrzech, w Ziemi Borsa ${ }^{87}$. Udało im się utworzyć komturstwo według typu nakreślonego w złotej bulli z Rimini zaledwie w formie zarodkowej.

Po opanowaniu ziemi chełmińskiej w latach 1230-1233 Krzyżacy wykorzystali kasztelański ustrój grodowy i dość szybko stworzyli system komturstw. Główną rolę odgrywali komturowie najmocniejszych grodów w Toruniu, Chełmnie i Radzyniu. Do 1230 roku Chełmno było siedzibą biskupa pruskiego Chrystiana i jego kapituly, po tym okresie stało się siedzibą komtura krajowego ${ }^{88}$. Urząd komtura krajowego zniknął w początku XIV w.

Odmienną sytuację zastali Krzyżacy w Prusach. W pierwszej kolejności zakon dążył do rozbicia wielkich jednostek polityczno-wojskowych, jakie tworzyły poszczególne plemiona, by następnie z mniejszych jednostek terytorialnych, zwanych „ziemiami” tworzyć samodzielne jednostki administracyjne. Nadawano im podstawowe funkcje sądowe, skarbowe i gospodarcze. Główne składniki wskrzeszenia tego dość archaicznego ustroju terytorialnego odnajdujemy w umowie dzierzgońskiej z roku $1249^{89}$. Ziemie te zaczęto nazywać z czasem ,komornictwami”, a ludność w stosunku do władzy krzyżackiej oraz władzę krzyżacką w stosunku do ludności reprezentował komornik, w źródłach niemieckich występujący pod nazwą: kemmerer i scheffer ${ }^{90}$. Prawdopodobnie urząd komornika został zapożyczony ze stosunków polskich, na co wskazywałoby określanie jego zastęp-

${ }^{84}$ Urząd podskarbiego powstał w Prusach ok. 1240 roku i został wyniesiony do grona najważniejszych dygnitarz zakonu, co zapewne wiązało się z usprawnieniem organizacji finansowania władz centralnych. Jóźwiak, Centralne i terytorialne organy władzy zakonu krzyżackiego w Prusach, s. 197.

${ }^{85}$ Górski, Studia i szkice z dziejów Państwa Krzyżackiego, s. 41.

${ }^{86}$ Labuda, Studia krytyczne o początkach Państwa Krzyżackiego w Prusach i na Pomorzu, s. 86.

${ }^{87}$ Kuczyński, Wielka wojna z Zakonem Krzyżackim w latach 1409-1411, s. 58-59.

${ }^{88}$ Biskup, Labuda, Dzieje Zakonu Krzyżackiego w Prusach, s. 172.

${ }^{89}$ Pr. Ub., Bd. I, 218.

${ }^{90}$ Biskup, Labuda, Dzieje Zakonu Krzyżackiego w Prusach, s. 173. 
cy, jako podkomorzego - packmoren ${ }^{91}$. Komornik zastąpił grupę nobilów, kierujących wiecami poszczególnych ziem i plemion, a zwłaszcza wodza, po którym przejął funkcje wojskowe ${ }^{92}$. Był związany z systemem skarbowym, a wśród jego kompetencji na pierwszy plan wysuwa się zadanie reprezentowania na terenach osadnictwa pruskiego ekonomicznych interesów Krzyżaków. Ponadto komornicy pruscy przejęli od wieców uprawnienia policyjno-prokuratorskie, pełniąc rolę pośredników między komturami a wiecami. Ponieważ Prusowie wybrali dla siebie ustrój administracyjno-sądowy i skarbowy według zasad prawa polskiego, komornik był również określany mianem włodarza (vloder). Nad komornictwami, jednostkami nadrzędnymi były komturstwa ${ }^{93}$.

Podział terytorialny ziemi chełmińskiej i Prus nie był zbudowany na jednolitych zasadach. W ziemi chełmińskiej początkowo został przez Zakon utrzymany dawny podział z czasów piastowskich, dopiero później wprowadzono nowy ${ }^{94}$, oparty na zasadach militarnych i gospodarczych. Natomiast system komturstw w Prusach rozwijał się powoli, w miarę dokonywania podboju tych ziem. Zdaniem Gerarda Labudy komturstwa w ziemi chełmińskiej ${ }^{95}$ i w Prusach zaprowadzono w 1246 roku podczas pobytu wielkiego mistrza Henryka von Hohenlohe na tym terenie. Wiązało się to $\mathrm{z}$ likwidacją wielu do tej pory istniejących grodów pruskich, a także z utrzymaniem przy życiu kilkunastu grodów naczelnych. Czasami grody naczelne nawiązywały do poprzednich grodów pruskich, a czasem były tworzone od nowa, głównie na pograniczu prusko-litewskim i na terenie Wielkiej Puszczy ${ }^{96}$.

Wszystkie nowo tworzone komturstwa powstawały na szlaku podbojów krzyżackich w pierwszym etapie ekspansji militarnej Krzyżaków. W pierwszej kolejności wzdłuż Wisły (Kwidzyn, Zantyr i Elbląg) w latach trzydziestych XIII w., potem wzdłuż Zalewu: Bałga, Dzierzgoń jako przedłużenie Elbląga w głąb kraju Pomezanów w roku 1247, oraz Królewiec, Kłajpeda i Pokarmin (niem. Brandenburg). Wszystkie komturstwa były dostępne drogami wodnymi, co zapewniało stałą komunikację i aprowizację. W skład komturstwa wchodziły także okręgi rolnicze, co miało duże znaczenie gospodarcze i militarne. Na obszarach można było lokować wsie na prawie niemieckim. Każde komturstwo miało pewną liczbę ludności pruskiej i odcinek granicy do strzeżenia, co sprawiało, że nie było szczególnie uprzywilejowanych okręgów. Wraz z poszerzaniem się terytorium krzyżackiego podporządkowano im tereny ciągnące się w kierunku Pojezierza i „Wielkiej Puszczy". Pod koniec XIII w. powstało komturstwo w Ragnecie dla teryto-

${ }^{91}$ J. Powierski, O zakonie krzyżackim. Uwagi na marginesie nowej syntezy Karola Górskiego, „Przegląd Zachodni”, 4 (1978) s. 32.

92 Tamże, s. 33.

${ }^{93}$ Tamże, s. 100 i n.

${ }^{94}$ Górski, Studia i szkice dziejów Państwa Krzyżackiego, s. 43.

${ }^{95}$ Bezpośrednim następstwem dokonanego podziału diecezji chełmińskiej było pojawienie się urzędu komtura ziemi chełmińskiej. Jóźwiak, Centralne i terytorialne organy władzy zakonu krzyżackiego w Prusach, s. 45.

${ }^{96}$ J. Powierski, Uwagi o udziale Prusów w genezie struktury stanowej państwa krzyżackiego, „Acta Universitatis Nicolai Copernici. Historia, 18 (1982) s. 26 i n. 
rium plemiennego Nadrowów. Najpóźniej zorganizowano tereny galindzko-jaćwięskie, tworząc dla nich komturstwo w Ostródzie. Początkowo największe znaczenie posiadały komturstwa ${ }^{97}$, w których obok komturów urzędowali: w Elblągu - mistrz krajowy, w Dzierzgoniu - wielki szpitalnik oraz wielki szatny, w Królewcu - wielki marszałek. Siedzibę zlikwidowanego komturstwa w Zantyrze w 1279 roku przeniesiono do pobliskiego Malborka (niem. Marienberg), dokąd w roku 1309 przeniesiono siedzibę wielkiego mistrza ${ }^{98}$.

Obok rezydującego w Chełmnie mistrza krajowego, w roku 1248 pojawił się komtur ziemi chełmińskiej, którym był Henryk von Merwitz, zajmujący jednocześnie nadrzędne stanowisko w stosunku do innych komturów tej ziemi ${ }^{99}$. Przejściowo pojawił się podział nadrzędny w postaci komturstwa całej ziemi chełmińskiej, sambijskiej i natangijskiej. W początkowym okresie w ziemi chełmińskiej były tylko cztery komturstwa: w Nieszawie, Chełmnie, Toruniu i Radzyminie. W drugiej połowie XIII w. ich liczba wzrosła. W roku 1274 i 1278 na terenie Chełmna występowało, aż dwóch komturów, z których jeden sprawował funkcję komtura krajowego chełmińskiego, a drugi rezydował w Starym Chełmnie ${ }^{100}$. Po 1285 roku siedziba komtura ziemi chełmińskiej mieściła się w Lipienku, co było związane z zakończonym procesem rozbudowy administracji konwentualnokomturskiej dla ziemi chełmińskiej. Ponadto od tegoż roku dygnitarzowi temu podlegały obszary, które na przełomie lat trzydziestych i czterdziestych XIV w. weszły w skład utworzonych wówczas trzech jednostek administracyjnych: komturstwa brodnickiego, wójtostwa lipieneckiego oraz zapewne wójtostwa nowomiejskiego ${ }^{101}$. Do kompetencji komtura ziemi chełmińskiej należało egzekwowanie obowiązku służby wojskowej ze strony posiadaczy dóbr służebnych, sprawowanie sądownictwa nad podległym mu rycerstwem, ponadto od końca XIII w. miał do dyspozycji swych kompanów. W pewnych okresach pojawili się też, komturowie innych ziem pruskich: komtur Sambii (1254), Natangii (1257), oraz Barcji (1257). W 1263 roku pojawiła się wzmianka o komturstwie w Bierzgłowie koło Torunia. W latach 80-tych XIII w. utworzono komturstwo w Unisławiu, niedaleko Starogardu, oraz w Papowie biskupim - zlikwidowane w 1421 roku. Również w tym okresie powstały grody, a wraz z nimi komturstwa ${ }^{102}$ w Grudziądzu, Rogoźnie, Wieldządzu, Pokrzywnie, Kowalewie (oba zlikwidowane po roku 1415) i w Gołubiu. Zakon w XIII w. zniósł komturstwo w mieście Chełmnie, a w początkach XIV w. Rogoźnie, Unisławiu i Wieldządzu ${ }^{103}$. Wójtowie i włodarze

${ }^{97} \mathrm{~W} 1251$ roku Elbląg ustanowiono siedzibą głównego konwenty i miejscem obrad corocznej kapituły prowincjonalnej. Pr. Ub., Bd. I, nr 251.

${ }^{98}$ J. Powierski, Chronologia początków Malborka, „Zapiski Historyczne”, 44, 1979, s. 5-32.

${ }^{99}$ Biskup, Labuda, Dzieje Zakonu Krzyżackiego w Prusach, s. 202.

${ }^{100}$ Tamże, s. 204.

${ }^{101}$ Jóźwiak, Centralne i terytorialne organy władzy zakonu krzyżackiego w Prusach, s. 45-48.

${ }^{102}$ Zakon z czasem tworzył nowe jednostki administracyjne wydzielając je z terytoriów już istniejących komturstw, np. na obszarach tworzących komturstwo toruńskie wyodrębniono komturstwa w: Bierzgłowie, Kowalewie i częściowo w Golubiu. Więcej zob. Jóźwiak, Centralne i terytorialne organy władzy zakonu krzyżackiego w Prusach, s. 55-64.

${ }^{103}$ Pr. Ub., Bd. I, nr 251. 
jako pełnomocnicy komtura odgrywali dużą rolę w zarządzie ekonomicznym komturstw. Urząd wójta nie istniał w żadnym z baliwatów poza Prusami i Inflantami ${ }^{104}$. Wójtowie często rezydowali wspólnie z komturami, lecz w odróżnieniu od nich byli często określani nazwami prowincji lub plemion. Do ich kompetencji należał pobór świadczeń od miejscowej ludności, sprawowanie sądów zarówno nad ludnością pruską jak i nad mieszkańcami lokowanych wsi na prawie niemieckim oraz dowodzenie oddziałami złożonymi z autochtonów ${ }^{105}$. Ponadto wójtowie zajmowali się odmierzaniem nadawanych dóbr, potwierdzaniem sprzedaży i kupna posiadłości. Pierwsze wójtostwa dla Sambii i Natangii (zlikwidowane pod koniec XIII w.) pojawiły się w latach siedemdziesiątych XIII w. i podlegały zwierzchnictwu komturów: królewieckiego i bałgijskiego (możliwe, że czasowo pokarmińskiego) ${ }^{106}$.

W Prusach także ośrodkami komturstw były grody, lecz w przeciwieństwie do ziemi chełmińskiej było ich bardzo mało. W Pomezanii wzdłuż Zalewu utworzono kilka komturstw, do których z kolei przydzielono tereny ciągnące się wzdłuż kraju, głównie z północy na południe. Komturstwo w Dzierzgoniu ${ }^{107}$ objęło dwie trzecie Pomezanii i ziemię sasińską. Dla Żuław zorganizowano komturstwo w Zantyrze, przeniesione w 1286 roku do Malborka. Najbardziej zwarte było komturstwo w Elblągu obejmujące ziemię: łężańską, pogezańską i pasłęcką. Na terenie Barcji i Natangii powstały komturstwa w Bałdze, Brandenburgu (Pokarmin), z których w 1326 roku wydzielono osobny okręg w Gierdanach. Komturstwo w Królewcu obejmowało krzyżackie posiadłości Sambii i Nadrowii; w jego zasięgu znajdowały się grody w Tapiawie, Welawie i Wystruciu, w których później powstały osobne komturstwa ${ }^{108}$.

W okresie walk z Litwą na wschodzie powstały komturstwa w Ragnecie i Kłajpedzie (niem. Memel). Oba komturstwa nie były samowystarczalne. W Ragnecie komturstwo powstało w 1289 roku na miejscu grodu Skalowów zdobytego w 1277 roku, natomiast komturstwo w Kłajpedzie należało już do prowincji kurlandzkiej. W Prusach komturstwa dysponowały silnie rozwiniętą siecią wójtostw, komornictw i urzędów leśnych, zarządzających gospodarką kraju. W tym miejscu należy zaznaczyć, że ogólny zarys pierwotnego podziału przetrwał do upadku państwa zakonnego ${ }^{109}$.

W państwie krzyżackim obok administracji terytorialnej zakonu istniała sieć administracyjna poszczególnych biskupstw z ośrodkami w Lubawie, Prabutach, Braniewie oraz na Sambii. W strefie jaćwięskiej taką administrację zaczęto orga-

${ }^{104} \mathrm{~W}$ sformułowanych przed 1309 roku Statutach zakonnych nie występuje żadna wzmianka o funkcji wójta. Jóźwiak, Centralne i terytorialne organy władzy zakonu krzyżackiego w Prusach, s. 64.

${ }^{105}$ Tamże, s. 64-72.

${ }^{106}$ Tamże, s. 187.

${ }^{107}$ Komturstwo w Dzierzgoniu powołano do życia w 1250 roku po uprzednim wydzieleniu zasięgu terytorialnego biskupów pomezańskich. Tamże, s. 54.

${ }^{108}$ Biskup, Labuda, Dzieje Zakonu Krzyżackiego w Prusach, s. 205.

${ }^{109}$ Górski, Studia i szkice z dziejów Państwa Krzyżackiego, s. 83 i n. 
nizować dopiero w XIV $\mathrm{w}^{110}$. Podział diecezjalny Prus w znacznym stopniu rozbijał podział plemienny: do diecezji chełmińskiej weszła część terytorium Sasinów - ziemia lubawska, do diecezji pomezańskiej poza Pomezanią i spornymi przedtem terenami nadwiślańskimi - części Pogezanii i mała część Sambii i Nadrowii, natomiast do diecezji sambijskiej inne terytoria plemienne. Rozbijanie organizacji plemiennej był to rys charakterystyczny dla powstającej państwowości krzyżackiej, dla której istotną przeszkodą były tradycje plemienne ${ }^{111}$.

Podobnie jak podziały diecezjalnie nie pokrywały się z plemiennymi, tak samo rozdzielenie diecezji na trzy części między zakon i biskupów całkowicie rozmijało się z zasięgiem terytoriów plemiennych, a granice poszczególnych diecezji wyznaczali sami Krzyżacy ${ }^{112}$.

Wszyscy komturowie chełmińscy i Pruscy od roku 1251 podlegali władzy mistrza krajowego. W komturstwie rezydował konwent złożony z 12 rycerzy i 6 księży (liczba minimalna). Na czele konwentu stał komtur łączący funkcje zakonne, administracyjne i wojskowe. W zasadzie prawie każdy z braci pełnił funkcję urzędniczą i wicekomtura, lub inaczej komtura domowego ${ }^{113}$, marszałka, szpitalnika, szatnego, skarbnika, rybickiego, itp. W skład konwentu wchodzili również półbracia (giermkowie) i bracia służebni, którzy składali śluby czasowe, na okres pełnienia służby wojskowej, czasami jednak śluby wieczyste. Bracia służebni ${ }^{114}$ pełnili $\mathrm{w}$ administracji niższe funkcje. Znaczny był w zakonie udział ministeriatów, co czyniło z niego instytucję zainteresowaną umocnieniem swej podstawy gospodarczej. Jeszcze w XIII w. spotykamy w zakonie osoby pochodzenia mieszczańskiego, w późniejszym okresie, osoby takie stanowiły wyjątek. Zakon tym samym stał się domeną niemieckiej szlachty. Stare statuty krzyżackie, tzw. Prawa za morzem, stwierdzają, że ten: ,kto nie jest urodzony w rodzie rycerskim, nie może być przyjęty do braci rycerzy" ${ }^{115}$, chyba, że w drodze wyjątku pozwoli na to wielki mistrz.

W komturstwie, jako samodzielnym okręgu, cały dochód należał do konwentu, a jedynie określone sumy mogły być na zasadzie szczegółowych postanowień przekazywane do skarbca w Malborku. Dochody komturstw szły na utrzymanie konwentów, które mogły gromadzić własne kapitały ${ }^{116}$.

\footnotetext{
${ }^{110}$ Biskup, Labuda, Dzieje Zakonu Krzyżackiego w Prusach, s. 205.

${ }^{111}$ H. Łowmiański, Początki Polski, Warszawa 1964-1973, t. 4, s. 42 i n.

112 Tenże, Studia nad poczatkami społeczeństwa i państwa litewskiego, t. 2, Wilno 1932, s. 644.

${ }^{113}$ Komtur domowy zastępował komtura w czasie jego nieobecności, występował w jego imieniu podczas spraw sądowych oraz odpowiadał za finanse i gospodarkę w siedzibie komturstwa i podporządkowanych mu dobrach. J. Tandecki, Podziały administracyjne państwa zakonnego w Prusach, w: Państwo zakonu krzyżackiego w Prusach, red. Z. H. Nowak, s. 19.

114 Bracia służebni nie przechodzili do braci - rycerzy zob.: K. Górski, Nowe spojrzenie na Krzyżaków, „Zapiski Historyczne”, 28 (1963) z. 1, s. 39-48.

${ }^{115}$ E. Potkowski, Rycerze w habitach, Warszawa 2004, s. 127.

${ }^{116}$ Górski, Studia i szkice z dziejów Państwa Krzyżackiego, s. 42.
} 
Okręgi niesamodzielne znajdujące się pod zarządem wójtów, prokuratorów, nadleśnych i rybickich były zobowiązane przekazywać dochody do komturstwa lub skarbu wielkiego mistrza.

Komturstwa dzieliły się na mniejsze okręgi, gdzie nie zawsze rezydowali bracia zakonni. Centrami tych okręgów były dwory, oddane w zarząd braciom służebnym. Liczba komturstw nie była stała. $Z$ biegiem czasu w tym dość zwartym podziale zaczęły powstawać wyłomy. I tak, np. rozwój południowych części komturstwa dzierzgońskiego, doprowadził do powstania nowego ostródzkiego. Obszar biskupstwa warmińskiego przerwał jedność terytorialną komturstwa elbląskiego, od którego odcięta została ziemia szczycińska ${ }^{117}$.

Ziemie biskupie często znajdowały się pod zarządem wójtów - Krzyżaków, mianowanych przez biskupów dla ziem, którymi sami zarządzali lub przez kapituły - dla ziem kapitulnych. Sądy nad miejscową ludnością polską i pruską sprawował komtur przy pomocy osobnego sędziego ${ }^{118}$.

Administracja Zakonu Krzyżackiego miała charakter hierarchiczny i centralistyczny. Była silnie rozbudowana, co sprawiało, że jej koszty utrzymania były wysokie. Niektóre urzędy, jak np. piwnicznego, ogrodnika czy zwierzchnika młynów były zbyteczne, inne natomiast mogły być skumulowane. W późniejszym okresie, po roku 1410 znoszono komturstwa, w których konwenty nie były się w stanie utrzymać.

Zakon Krzyżacki na własnym obszarze państwowym planowo znosił wszystkie zastane instytucje władzy publicznej. Krzyżacy pozostawili jedynie samorząd $\mathrm{w}$ miastach i na wsi w ramach prawa polskiego, pruskiego i niemieckiego. Powstanie organizacji komturskiej umożliwiło zwiększenie nadzoru nad terenami zwartego osadnictwa pruskiego. Ustrój administracyjny Prus Krzyżackich nie miał wpływu na kraje ościenne; wyjątek stanowił urząd chorążego ziemskiego na Litwie, który podobnie jak w Prusach zajmował pierwsze miejsce wśród urzędników ziemskich ${ }^{119}$.

\section{Podsumowanie}

Krzyżacy w Prusach i ziemi chełmińskiej stworzyli państwo zakonne, którego potęga przerosła inne państwa zakonne. Na ten sukces wpływ miało wiele czynników. Przeniesione nad Bałtyk zasady kolonialne potrafili doskonale dostosować do panujących stosunków wschodnioeuropejskich. Krzyżacy potrafili zespolić dwa różne co do stopnia rozwoju poziomy organizacji państwowej. Jeden odpowiadający rozwiniętej państwowości feudalnej, i drugi, związany z podłożem pruskim, przypominający swoimi cechami najwcześniejsze stadium państwowości wczesnofeudalnej. Jedynym błędem było niewłaściwe traktowanie nawróconych Prusów w pierwszym okresie budowy państwa. Krzyżacy potrafili dostosować się

${ }^{117}$ Tamże, s. 43.

${ }^{118}$ Biskup, Labuda, Dzieje Zakonu Krzyżackiego w Prusach, s. 203.

${ }_{119} \mathrm{~W}$. Kamieniecki, Chorażowie w parlamentaryzmie litewskim przed unia lubelska, ,Antemurale", 9 (1965) s. 165-203. 
do środowiska i znaleźć w nim oparcie. Miejscowej ludności zachowano jej prawo - polskie, lub stworzono nowe - pruskie, wobec opornych Prusów zastosowano poddaństwo na wzór palestyński. Zachowując prawo polskie czerpał zakon z niego korzyści fiskalne, stąd najdłużej prawo to zachowało się właśnie na Pomorzu.

Po dziesięciu latach od momentu przybycia do Prus Krzyżacy dotarli nad Pregołę, w ciągu kolejnych trzydziestu lat złamali dwa powstania pruskie, poszerzyli znacznie zdobyty obszar i wznieśli na nim wiele zamków. Dokonała tego mała liczebnie grupa Krzyżaków o wielkiej wartości bojowej i silnej wewnętrznej dyscyplinie ${ }^{120}$. Podboje terytorialne umożliwiały tworzenie i modyfikowanie administracji terytorialnej. Proces rozbudowy owej administracji został zahamowany w wyniku wybuchu drugiego powstania pruskiego. Wydzielono wówczas jedynie dwa nowe komturstwa z siedzibami w Grudziądzu i Bierzgłowie. Dopiero lata osiemdziesiąte XIII w. przyniosły dalszą wzmożoną rozbudowę administracji terytorialnej w Prusach. Po zawarciu układu milickiego, Krzyżacy w 1283 roku założyli pierwsze komturstwo na Pomorzu Gdańskim, a dwa lata później zakończył się proces rozbudowy administracyjnej struktury ziemi chełmińskiej ${ }^{121}$. Krótki żywot miały utworzone w latach osiemdziesiątych XIII w. w Prusach Dolnych nowe jednostki administracyjne, natomiast trwalsze okazaly się te utworzone na północno-wschodnim krańcu podbijanych Prus.

Struktura Zakonu Krzyżackiego w XIII w., którą odnajdujemy jako zalecenie w statutach była jak najbardziej odpowiednia do potrzeb zakonu. Struktura ta rozwijała się wraz z zakonem, dzięki czemu dawała zakonowi niezbędne oparcie. Wykształcone jeszcze w Ziemi Świętej wewnętrzne struktury Zakonu Krzyżackiego, okazały się przydatne, m.in. w procesie budowy własnego państwa w Prusach, gdzie stworzono praktyczne i niezwykle sprawne struktury. To co stanowiło w XIII w. o sile zakonu, w przyszłości miało stać się jego słabością. Kostniała bowiem duchowa treść tych struktur, Zakon Krzyżacki przestał dopasowywać się do zmienionej rzeczywistości. Zamiast wprowadzić zmiany w statutach zakonu, wciąż odwoływał się do ich trzynastowiecznej wersji.

Prusy posiadały przejrzystą formę urzędów. Obszar Prus podzielony był podobnie, jak w państwie nowożytnym na małe jednostki regionalne. Stworzone przez zakon struktury administracyjne w Prusach wydają się bardziej nowoczesne niż większość funkcjonujących w innych krajach, ponieważ w państwie zakonnym zarządzano obszarem zwartym, o niskim stopniu rozdrobnienia feudalnego. Zarządzający rycerze zakonni - komturowie, wójtowie podlegali rotacji, zgodnie $\mathrm{z}$ regułą zakonną. Wszyscy bracia zakonni, poza wielkim mistrzem, pełnili swoje funkcje tylko przez pewien czas, co z pewnością ograniczało korupcję. Dobrze zorganizowane struktury władzy były jednym z czynników decydujących o sile państwa krzyżackiego.

${ }^{120}$ Rocznik Krasińskich, pod datą 1234 podaje, że pierwsi Krzyżacy jaśnieli „świętością życia”. Oznacza to, że choć okrutni na wojnie, przestrzegali w życiu codziennym moralnych przepisów reguły, po stratach poniesionych w walce z Prusami obniżono wymagania, co zaważyło w przyszłości na całym wizerunku zakonu. Monumenta Poloniae Historica, t. V, Warszawa 1961, s. 132.

${ }^{121}$ K. Bruski, Ziemie nad Dolna Wierzyca od XIII do poczatku XV wieku, Gdańsk 1997, 65 i n.; Jóźwiak, Centralne i terytorialne organy władzy zakonu krzyżackiego w Prusach, s. 60. 


\title{
THE ORGANIZATION OF THE ADMINISTRATION OF THE STATE OF THE TEUTONIC ORDER IN PRUSSIA UNTIL THE END OF THE 13TH CENTURY
}

\begin{abstract}
Summary
Formed during the crusading movement, the Teutonic Knights developed the internal structures in the Holy Land after the act of 1198, structures which survived several centuries and proved to be very useful in the process of building their own state in Prussia. The following work briefly presents the offices of the deputy of the Grandmaster and the chief of military affairs, the official responsible for all hospital affairs, the official responsible for dressing and armament, the treasurer and the castellan. All these officials, except for the castellan, formed the group of the great nobles in Prussia from the 14th century. The increase in property outside the Holy Land contributed to the vertical power structure. A pioneering period in the history of the Teutonic Knights ended during the reign of Grand Master Hermann von Salza; then a new period of building their own state on the Baltic began. Equipped with the imperial privilege, the Teutonic Knights came to the Vistula, where they received from Konrad Mazowiecki in 1230 the privilege conferring the land of Chelmn on them, the land which was the territorial base of their future activity in Prussia. Since then, supported by the knights from western Europe and Germany, they systematically had been conquering Prussia. In the early period of the conquest Polish dukes also helped them. The Teutonic Knights were the winners in the dispute with the Bishop of Prussia, Christian. After suppressing two Prussian uprisings and conquering the land of Jaćwież, the Teutonic Order reached the line of the Niemen and strengthened its reign in the whole Prussia. The organization of the formed religious state was of monarchical type. Dualistic, that is, theocratic and feudal character of the state affected administrative divisions introduced by the Knights. They built well functioning administration, whose characteristic feature was the division into commandries. Although the number of commandries was not steady and the range of their influence would change, generally the primary administrative divisions survived until the fall of the monastic state in Prussia. Among the source material used in this work the chronicles included in Scriptores Rerum Prusicarum are of the basic importance. These chronicles are as follows: The Prussian Chronicle by Peter of Dusburg, The Chronicle of Oliwa by Abbot Stanislaus. In addition, the author used works by German and Polish historians such as: the works of Gerard Labuda, Marian Biskup, Sławomir Jóźwiak, the collective work edited by Zenon Hubert Nowak, S. Kujot, Hartmut Boockmann, Udo Arnold. The full list of the used sources and literature is in the footnotes.
\end{abstract}

